\title{
THE MODEL OF JUSTICE AND COMMITMENT IN THE EVALUATION OF STUDENT'S PERFORMANCE
}

\author{
Hunik Sri Runing Sawitri \\ Asri Laksmi Riani \\ Malik Cahyadin \\ Intan Novela Q. A. \\ Faculty of Economic, Sebelas Maret University, Surakarta \\ Jl. Ir. Sutami No. 36A, Surakarta 57126 \\ Email: hunik_sri@yahoo.co.id
}

\begin{abstract}
This study aimed to examine the importance of justice in students' performance evaluation which might foster students' commitment to lecturers, and as a consequence students would perform well. The research was conducted on students from departments of Sebelas Maret University who had undertaken competency-based learning; and used stratified sampling. Regression analysis was used to test the hypotheses. The results showed that students' commitment to lecturers did not significantly influence students' performance. Distributive and procedural justice in controlled commitment did not significantly influence students' performance. On the other hand, procedural and distributive justice significantly influenced students' commitment to lecturers.
\end{abstract}

Keywords: Competency-Based Learning, Justice, Commitment, Students' Performance

\begin{abstract}
Abstrak
Penelitian ini bertujuan untuk menguji pentingnya keadilan dalam evaluasi hasil pembelajaran yang kemudian menumbuhkan komitmen mahasiswa pada dosen, sehingga mahasiswa berkinerja baik. Penelitian dilakukan terhadap mahasiswa Universitas Sebelas Maret dari fakultas yang telah mengalami PBK dengan pengambilan sampel secara stratified sampling. Uji Hipotesis dilakukan dengan analisis regresi. Hasil menunjukkan bahwa komitmen tidak secara signifikan mempengaruhi kinerja mahasiswa. Keadilan distributif maupun prosedural dikontrol komitmen tidak berpengaruh secara signifikan pada kinerja mahasiswa. Sementara keadilan prosedural distributif secara signifikan mempengaruhi komitmen mahasiswa.
\end{abstract}

Kata Kunci: PBK, Keadilan, Komitmen, Kinerja Mahasiswa

\section{INTRODUCTION}

Globalization and the advancement of science and technology demand universities and colleges to produce graduates with high competitive qualities. Education is expected to produce human resources which have excellent qualities as assets to win the high competition in obtaining jobs. Graduates' competencies should be able to meet the requirements of their clients, each graduate should be competent in his or her field of study. The educational program which emphasizes this concern is called competencybased education or education with competency-based curiculum (Tim LPP UNS or LPP Team of Sebelas Maret University). In accordance with the Decree of National Education Minister No. 232/U/2000 and No. 045/U/2000, University or College curiculum was changed from content-based curiculum to competency-based curiculum. At present, Sebelas Maret University has adopted the competency-based curiculum although the implementation is not yet satisfactory. Competency based curiculum requires lecturers to provide opportunities and facilities, and to awaken motivation in students so that they can achieve the competencies targeted for them. In agreement with the assumption that learning is a system which consists of input, process, and output, one of the crucial task of lecturers is evaluating the process and result of learning.

Therefore, the main subject of this study was the evaluation of learning result, among others: whether lecturers apply justice when grading students' tests or assignments; whether the justice recognized by the students led to students' commitment to lecturers; 
whether the commitment urged students to perform better which could be seen in their grade point average (GPA). In pursuing their studies, students expected to get good grades as a consequence of their hard work in order to meet the requirements that had been agreed by lecturers and students.

In reality, some students suspected that the grades given to them were determined as by lottery (Joglosemar, March 20, 2010). The students felt that they were treated unjustly dan their grades did not show their actual performance. The unjust treatment would lead to feelings of anger, hatred and cruelty in the students. Then those feelings provoked perverse behaviors which disturbed the effort to achieve good performance (Skarlicki \& Folger, 1997).

The justice in students' performance evaluation included procedural justice and distributive justice. Distributive justice related to students' perception of the grades given by lecturers, while procedural justice related to students' perception of the policies and procedures that were applied in determining the grades (Skarlicki \& Folger, 1997; Colquitt, 2001). Thus, it was not enough for students just to be given grades by lecturers. They should also know the policies and procedures employed by lecturers in determining the grades.

Tang \& Sarsfield-Baldwin (1996) stated that when people were justly treated in procedures, they tended to become loyal, which indicated commitment. Their study found that distributive and procedural justice were important predictors of organizational commitment. This agreed with the findings of Solikhin \& Pike (2009) which proposed that justice in the procedure of performance evaluation had a relationship with commitment.

Commitment to manager or supervisor resulted in the acceptance of the norms of work, so that it tended to improve employees' performance (Becker et al., 1996). Commitment to manager or supervisor was an important predictor of employees' performance (Becker, 1992; Becker et al., 1996; Chen et al., 2002). These findings indicated that when students' had commitment toward their lecturers, they would accept the norms set in the relationship between students and lecturers, which would result in the improvement of students' performance.

\section{THEORETICAL BASE AND HYPOTHESES}

\section{Competency-Based Learning System}

Based on the Law of the Republic of Indonesia No. 20 Year 2003 about National Education System, the curiculum model which must be applied in all levels of education in Indonesia in order to raise the quality of education is competency-based curiculum. Competency-based curiculum in universities or colleges emphasizes on the achievement of a specific competency by a graduate which meets the requirements of his or her clients. Thus, achievement of competency becomes the measurement of success in university or college education. It is expected that competency-based curiculum may contribute to national excellence so that our nation has competitive advantage in global level.

According to the Decree of National Education Minister No. 045/U/2002, competency comprises a set of intelligent and accountable actions which should be owned by a person in order to be deemed capable by the community to carry out assignments in a specific field of work. Accordingly, the competency level of a graduate is determined by the community. Therefore, the competency that is applied as reference in evaluating a student's success in his or her university or college education should be based on the demand of the market.

Several other definitions of competency, as quoted by Tim LPP UNS (LPP Team of Sebelas Maret University) include:

a. Competency comprises knowledge, skill and ability that must be mastered and become a part of a person's self, so that he or she can present them through cognitive, affective, and psychomotoric behaviors satisfactorily. In education program, this is asserted as the specific purpose of education to be achieved.

b. Competency is a statement which describes a visible presentation of combined skills.

c. Competency is a basic characteristic in a person which relates to the presentation of combined skills in a standard of excellence in order to fulfill an assignment or to meet a situation. According to this definition, competency has five traits, namely: (1) motive: the urge to act; (2) hereditary disposition: the consistent response shown to a certain stimulus; (3) concept of self which includes: attitudes, values, and self image; (4) knowledge: mastered information of a certain field; and (5) skill: the ability to carry out certain assignments physically and mentally. However, not all these traits are easy to be developed.

d. Competency comprises knowledge, skill, and principle values which are reflected in habitual thoughts and actions (Department of National Education, 2002). According to Burke (1995), competence is being able to perform whole work roles, to the standards expected in employment, in real working environment. This definition indi- 
cates three criteria of competency, namely: (1) able to carry out all the tasks of a job, instead of having skills for a specific task of a job; (2) can meet the requirements demanded by a job; and (3) can perform well in a job which emphasizes on and relates with the whole job and its actual variations.

e. The report of SCANS (1991) identifies five competencies and three basic skills which must be mastered by a person to be able to perform a job well. The five competencies include: (1) resource: identifies, plans, and allocates resources; (2) interpersonal: works well with others; (3) information: acquires and uses information; (4) systems: understands complex interrelationships; (5) technology: works with a variety of technology. While the three basic skills include: (1) basic of skill: reads, writes, performs arithmetic, mathematical operations, and listens and speaks effecttively; (2) thinking skills: thinks creatively, makes decision, solves problems, visualizes, knows how to learn, and reason, and (3) personal qualities: displays responsibilities, self esteem, sociability, selfmanagement, integrity, and honesty.

Competency-based learning is the implementation of competency-based curiculum. One of the chief activities of competency-based learning is the evaluation of the competency-based learning which includes evaluation of input, process, and output of the learning system.

a. Evaluation of Input

Emphasizes on the evaluation of students' characteristics, sufficiency and condition of learning means and infrastructures, lecturers' characteristics and capabilites, curiculum and learning materials, learning strategies which correspond with the subjects learned and the environment of the learning place.

b. Evaluation of Process

Emphasizes on the evaluation of the execution of learning by lecturers which includes learning strategies, the effectiveness of learning tools, teaching methods which correspond with students' interests, attitudes, and learning patterns.

c. Evaluation of Output

Applying tests to measure students' performance in learning, in this case, the mastering of competency by each student.

The learning evaluation observed in this study was the evaluation of output (the evaluation of learning result).

\section{Relationship between Commitment and Perfor- mance}

The results of studies on the relationship between organizational commitment and performance were not consistent. Several studies obtained positive findings (Suliman \& Iles, 2000; Kelidbari et al., 2011; Qaisar et al., 2012), other studies did not find any relationship between the two issues (Meyer \& Allen, 1991), and several other studies even found negative relationships (Chen et al., 2002; Meyer \& Allen, 1991; Becker et al., 1996; Jaros, 1997; Somer \& Birnbaum, 1998). Kelidbari et al. (2011) found that higher organizational commitment related to performance, especially the normative commitment. While Qaisar et al. (2012) found that affective, normative, and continuance commitment related to employees' performance.

Employees' commitment can be directed to various targets. Excepting organization target, commitment can be directed to other targets such as work, top management, supervisor, colleagues, work department, customers, labor union, and or public in general (Becker, 1992; Becker et al., 1996; Reichers, 1985; Meyer et al., 1993; Chen et al., 2002). Among those commitments, commitment to organization showed a weak relationship to performance and was not consistent, while commitment to supervisor was relatively consistent in the relationship with performance. This commitment to supervisor was an important predictor of performance (Becker, 1992; Becker et al., 1996; Chen et al., 2002).

Fishbein \& Ajzen in Becker \& Kernan (2003) stated that commitment to a certain target (supervisor or lecturer) had implication on the target. The Theory of Reasoned Action (TRA) proposed by Fishbein \& Ajzen in Becker \& Kernan (2003) assumed that certain attitudes related to behavior only as long as the target of the attitudes and the behavior was the same. For example, a student's attitude to a lecturer is a better predictor of the lecturer. The same logic applied in this statement: commitment to a certain target had implication on that target and not on other targets (Becker \& Billing in Becker \& Kernan, 2003). From the proposition, we formulated the following hypo-thesis:

$\boldsymbol{H}_{I}$ : Commitment to lecturers had a positive influence on students' performance

\section{Relationship between Justice and Commitment}

One important factor in competency-based learning is learning evaluation. Learning evaluation includes evaluation of input, process, and output or result of the learning system (PPSP-LPP UNS or PSPP-LPP Team of Sebelas Maret University). 
Evaluation of process and output or result were more emphazised in this study since these two evaluations constitute very important learning components.

Anderson \& Krathwohl in Tantra (2009) stated that competency was conceptualized in behavior as the result of interaction of cognitive, affective, and psychomotoric aspects. The evaluation of learning result with regard to cognitive, affective, and psychomotoric aspects involved students' perception of justice. Students' perception of lecturers' justice in evaluating their learning performance would influence students' commitment to lecturers. In agreement with the social exchange theory with its reciprocity norm, students' perception of justice would urge them to reciprocate by increasing their commitment to lecturers (Hemdi \& Nasurdin, 2006).

Several previous studies on the relationship between justice and commitment showed a positive relationship; thus, a person who had a good perception of justice tended to have a greater commitment (Tang \& Sarsfield-Baldwin, 1996; Nasrudin \& Ahmad, 2000; Rhoades et al., 2001; Colquitt et al., 2001; Ali \& Jan, 2012). Procedural and distributive justice positively and significantly related to commitment (Ali \& Jan, 2012). Distributive justice meant how far a reward was perceived to be justly given, while procedural justice meant how far a reward was perceived to be given through just (fair) procedures. More specifically, procedural justice (the procedure of determining students' grades) and distributive justice (the grades given) in the evaluation of learning performance perceived by students would lead to students' commitment to lecturers. Thus, justice tended to cause students to become loyal and partial to their lecturers, and to become strongly involved in and enjoy the learning process they are undertaking. The hypotheses that can be formulated from these assumptions is as follows:

$\boldsymbol{H}_{2}$ : Procedural and distributive justice relate positively with students' commitment to lecturers.

\section{RESEARCH METHOD}

This study belongs to descriptive and explanatory studies. A descriptive study is a study which describes the various characteristical phenomena of respondents and their behaviors, while an explanatory study is a study which explains the phenomena of the relationships among variables, based on previous theories and studies which used empirical data (Cooper \& Schindler, 2003). The operational definetions and variable measurements of this study are as follows:

1. Procedural justice. The justice which related to student's perception of the procedure employed by lecturer in determining student's grade, which was measured by seven items using the five scale of Thibaut \& Walker (1975) and Leventhal (1980).

2. Distributive justice. The justice which related to student's perception of the grade given by lecturer, which was measured by four items using the five scale of Leventhal (1980).

3. Commitment. Student's partiality and involvement in the learning process executed by lecturer. This included a strong believe in and an acceptance of the aim and value of the learning process (identification), the willingness to make a great effort according to lecturer's expectation and or according to the agreement between lecturer and student (involvement) and a strong will to always join the lecture given by lecturer (loyalty), which was measured by 17 items using the five scale of Chen et al. (2002).

4. Performance. The fulfillment of assignments and responsibilities related to learning process, and of competency tests given by lecturer, which was measured through student's GPA (grade point average).

This study was performed in two exact sciences departments and two non exact sciences department of Sebelas Maret University in the city of Surakarta which had applied the competency-based learning. From each department we took 50 students as samples. Firstly, we differentiated between students of exact sciences department and students of non exact sciences department. Then, using simple random technique, we took students of two departments for each group. The selection of departments was made with regard to generalization in order to represent all the exact sciences and non exact sciences departments of Sebelas Maret University.

The population were students of Sebelas Maret University who had undertaken instruction and learning process with the competency-based learning. The sampling method employed in the selected departments was stratified sampling, namely sampling by dividing the population into several subpopulations or stratas (Hartono, 2004). The strata in this study was semester, namely students of the fourth and sixth semesters.

This study used student's perception of justice in lecturer's evaluation of student's performance, commitment to lecturer, and student's GPA as primary data. Sampling was performed by distributing questionnaires to students. In order to obtain accurate and thorough data, the sampling was supplemented by focused group discussions (FGD) with previously prepared guidance. Data collecting Team helped to inter- 
view respondents in order to prevent misperception or misunderstanding about the questions in the questionnaire. This interview was continued with focused group discussions to probe students' attitude towards the learning process they were undertaking. The data obtained from focused group discussions was qualitative data.

The steps of data collecting in this study were as followed:

\section{Preparation}

In this phase we obtained permit, prepared questionnaire and data collecting Team. We made 50 exemplars of questionnaire for a try out to know the feasibility of the research instrument in the field.

2. Research Instrument Try Out and Data Collecting Our activity in this phase was collecting data from about 50 respondents to test the feasibility of the research instrument. This phase could be regarded as a preceding research which examined how far the research instrument could be understood by respondents, and which functioned as an instrument validity and reliability test (Hair et al., 2009). After evaluating and revising the try out results, we collected data using the revised instrument, until we obtained 200 research data. After we obtained data through the questionnaire instrument, we collected all qualitative data through focused group discussions.

3. Data Processing

The next phase was data processing phase. Data entry and data tabulation was done with the SPSS program. Then the data was used for further tests. Qualitative data was used to find out respondents' attitude towards the learning process they were undertaking.

To test the hypotheses which had been formulated, we used regression analysis. This analysis was performed by regressing commitment to lecturer variable with student's performance variable, then justice variable with commitment to lecturer variable. Next, we regressed commitment variable with performance variable by controlling distributive justice variable and procedural justice variable. The regression equation was as follows:

$$
\begin{gathered}
Y=a+b_{1} Z \\
Y=a+b_{2} X 1+b_{3} X_{2} \\
Y=a+b_{1} Z+b_{2} X_{1}+b_{3} X_{2}
\end{gathered}
$$

$Y=$ Student's performance

$X_{1}=$ Procedural justice

$X_{2}=$ Distributive justice

$Z=$ Student's commitment to lecturer
Students' attitude towards the learning process with competency-based curiculum could be known through descriptive analysis of the data or information obtained from interviews and focused group discussions. The flow of thoughts which had been discussed above could be pictured in a model as seen in Figure 1.

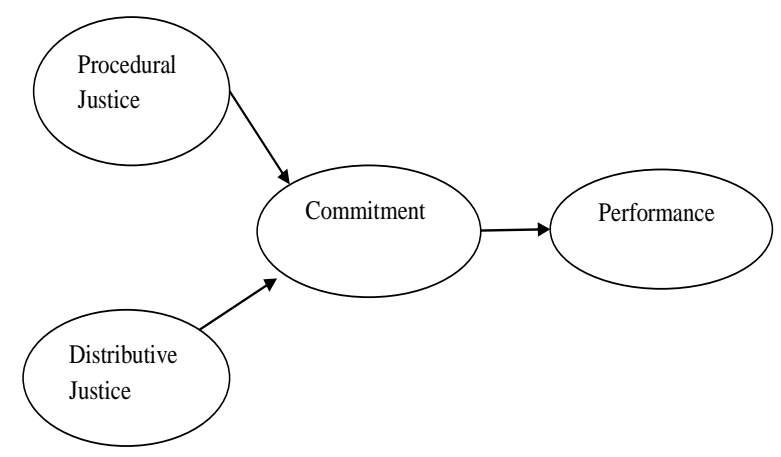

Figure 1. Model of the Relationships between Research Variables

\section{STUDY RESULTS AND DISCUSSION}

\section{Study Results}

From focused group discussions we found that competency-based curiculum had been applied in the process of instruction and learning. Every lecturer made a syllabus and explained the syllabus to students at the beginning of semester. In accordance with a rule in competency-based curiculum, every lecturer gives assignments to students, collectively or individually. The assignment might be done in class or at home. The problem in this case was that several lecturers might give assignments at the same time which burdened students because they could not divide their time for too many assignments. Other complaints of the students were: lecturer did not come to class on time, lecturer was absent without previous notice, the assignments given to students were sometimes not clear.

Table 1. Respondents' Characteristic According to Sex

\begin{tabular}{lrc}
\hline Sex & Total & Percentage \\
\hline Male & 107 & 53.50 \\
Female & 93 & 46.50 \\
\hline Total & 200 & 100 \\
\hline
\end{tabular}

Regarding sex, the larger part of the respondents were male, namely 107 persons $(53.50 \%)$, while female respondents were 93 persons $(46.50 \%)$. The respondents' age ranged from 19 to 22 years, according to the semesters they were undertaking, namely the fourth and sixth semesters, with GPA of 3.19. 
Table 2. Respondents' Characteristic According to GPA

\begin{tabular}{lcc}
\hline GPA & Total & Percentage \\
\hline GPA $<3$ & 30 & 15 \\
GPA $\geq 3$ & 170 & 85 \\
\hline Total & 200 & 100 \\
\hline
\end{tabular}

Respondents' responses to research variables showed that respondents perceived the existence of procedural justice and distributive justice, and respondents had commitment to lecturers. However, it should be noted that very many respondents selected the "neutral" answer, which indicated that respondents felt some doubts in answering the questions.

Before we carried out hypotheses tests, we ascertained that the research instrument had passed the validity test and the reliability test. We used Confirmatory Factor Analysis to test validity, and Alpha Cronbach to test reliability. The result was seven commitment items were not valid out of 17 items. Apart of that, all research instruments were valid and reliable. Hypothesis 1 which proposed that commitment to lecturer had a positive influence on performance was tested with simple regression analysis. The test result did not confirm the hypothesis.

Table 3. The Result of Regression Analysis of the Influence of Commitment on Performance (GPA)

\begin{tabular}{lcccc}
\hline Variable & $\begin{array}{c}\text { Standardized } \\
\boldsymbol{\beta}\end{array}$ & $\boldsymbol{t}$ & Sig. & $\begin{array}{c}\text { Adj } \boldsymbol{R} \\
\text { Square }\end{array}$ \\
\hline $\begin{array}{l}\text { Constant } \\
\begin{array}{l}\text { Commitment to } \\
\text { lecturer }\end{array}\end{array}$ & 3.146 & & 0.000 & -0.004 \\
\hline
\end{tabular}

From the result of the simple regression analysis given in Table 3, it can be seen that commitment to lecturer did not significantly influence student's performance (GPA), eventhough the tendency was as had been stated in theory. The values of $\beta$ was 0.031 and $t$ was 0.430 with the probability of $0.668>0.05$.

Table 4 shows the result of multiplied regression analysis used to test hypothesis 2 which proposed that procedural justice and distributive justice influenced commitment to lecturer. The result confirmed hypothesis 2 . The $\beta$ value of procedural justice was 0.333 and the $t$ value was 4.764 with the probability of $0.000<0.05$. The $\beta$ value of distributive justice was 0.262 and the $t$ value was 3.753 with the probability of $0.000<0.05$.

Then we tested the influence of commitment to lecturer by controlling distributive justice variable and procedural justice variable. The result is shown in Table 5 .
Table 4. The Result of Regression Analysis of the Influence of Justice on Commitment

\begin{tabular}{lcccc}
\hline \multicolumn{1}{c}{ Variable } & $\begin{array}{c}\text { Standar- } \\
\text { dized } \boldsymbol{\beta}\end{array}$ & $\boldsymbol{t}$ & Sig. & $\begin{array}{c}\text { Adj } \boldsymbol{R} \\
\text { Square }\end{array}$ \\
\hline & & & & 0.257 \\
Constant & 19.394 & 11.372 & 0.000 & \\
Procedural justice & 0.333 & 4.764 & 0.000 & \\
Distributive justice & 0.262 & 3.753 & 0.000 & \\
\hline
\end{tabular}

Table 5. The Result of Regression Analysis of the Influence of Justice and Commitment on Performance (GPA)

\begin{tabular}{lcccc}
\hline \multicolumn{1}{c}{ Variable } & $\begin{array}{c}\text { Standar- } \\
\text { dized } \boldsymbol{\beta}\end{array}$ & $\boldsymbol{t}$ & Sig. & $\begin{array}{c}\text { Adj } \boldsymbol{R} \\
\text { Square }\end{array}$ \\
\hline Constant & 3.201 & 23.779 & 0.000 & 0.004 \\
$\begin{array}{l}\text { Commitment to } \\
\text { lecturer }\end{array}$ & 0.062 & 0.753 & 0.452 & \\
$\begin{array}{l}\text { Distributive justice } \\
\text { Procedural justice }\end{array}$ & -0.095 & 1.131 & 0.070 & \\
\hline
\end{tabular}

In the previous analysis as shown in Table 3, commitment to lecturer did not significantly influence student's performance. Then after we controlled distributive justice and procedural justice (Table 5), we also found that commitment to lecturer did not significantly influence student's performance. Distributive justice and procedural justice did not significantly influence student's performance, either. Yet, when we regressed distributive justice and procedural justice with commitment to lecturer, we found that both distributive justice and procedural justice influenced commitment significantly. This result indicated that distributive justice and procedural justice seen by students in lecturers' evaluation of their performance obviously raised students' commitment to lecturers, however the commitment did not automatically improve students' performance.

\section{Discussions}

The hypotheses tests showed that distributive justice and procedural justice influenced students' commitment to lecturers significantly. This meant that students' commitment to lecturers was significantly influenced by students' perception of distributive justice and procedural justice applied by lecturers in evaluating students' performance. The grades given by lecturers to students, which were determined through processes or procedures set by lecturers, which included the components applied in grade determination, the proportion and the transparancy of each component, were carefully watched by students, which then determined their commitment to lecturers. 
However, when we looked at the description of the students' responses about procedural justice, we found that they did not strongly and openly stated that the procedural justice they saw so far was not as what they expected. This was indicated by the large number of students who selected "neutral" answers for the questionnaire items which related to procedural justice, especially the statement "I can influence the lecturer's procedure in evaluating student performance," which obtained neutral answer from 81 students, which far exceeded the number of students who agreed (45 students) and who disagreed (51 students).

This indirectly showed that students could not give suggestions to lecturers about the procedure of students' performance evaluation. Whereas, according to competency-based curiculum, when a lecturer gives his or her first lecture in the beginning of semester, the lecturer should explain to students about the performance evaluation procedure that has been set in the syllabus for each subject. Regarding the grading components and their proportions, the lecturer should ask if the students agree with the grading procedure, and offer students opportunity to give suggestions.

Distributive justice seemed to be also taken into students' consideration in determining their commitment to lecturers. This variable, in accordance with the result of the hypotheses tests, significantly influenced students' commitment to lecturers. Thus, when students perceived that the grades given by a lecturer were determined justly, then they would have commitment to the lecturer. Students would perceive distributive justice when the grades they obtained truly reflected their efforts in completing assignments and their contributions in class, or truly reflected their performance. This finding supported the findings of previous studies which stated that distributive justice was an important predictor of commitment (Folger \& Konovsky in Meyer \& Smith, 2000; Barling \& Philips in Witt et al., 2001).

Students' responses to statements about distributive justice did not differ greatly from the responses concerning procedural justice. Many students selected the neutral answer, although not as many as in procedural justice. This indicated that students did not see enough distributive justice; however they did not state it explicitly. This was understandable, since when the procedure was not just, then it was quite possible that the outcome might be lacking in justice, too.

Precious studies found that procedural justice was a better predictor of employyees' commitment than distributive justice. When employees were treated justly in procedures they did not question about distributive justice (Tang \& Sarsfield-Baldwin, 1996). This study implied that students deemed that they were given little chance to give suggestions about the grading procedure of lecturers. Therefore the grades they obtained were not as they expected because the grades did not reflect the efforts they had made in the learning process, so that naturally some students were of the opinion that their grades were determined as by lottery.

The next finding was that commitment to lecturer did not significantly influence student's performance (student's GPA). Thus, student's commitment to lecturer did not automatically improve student's GPA. This finding disagreed with the Theory of Reasoned Action which stated that certain attitude related to behavior only as long as the target of the attitude and the behavior was the same (Becker \& Kernan, 2003). Thus according to the theory, when students were committed to a lecturer, they would show a behavior which conformed to the lecturer's expectations which would result in improved GPA. However, the result of this study did not confirm this proposition.

When commitment to lecturer with distributive justice and procedural justice were regressed with student's performance, we still did not find significant influence on student's performance, while commitment to lecturer was formed by the justice seen by the students. The argument that we could present was that student's commitment to lecturer could not be clearly revealed by the indicators in the questionnaire of this study, since students' responses to other variables contained very many neutral answers, especially to statements related to lecturer.

Thus, it was quite possible that the data which had been collected did not truly reveal real commitment. This fact should be noted in future studies, regarding both indicator and scale. Other point of interest is the possibility of indirect relationship between commitment and performance; namely, there may be other variables which mediate the influence of commitment on performance. For example, the knowledge that lecturers checked the assignments students had completed could motivate students to do assignments as instructed by lecturers. A previous study found that relationship between commitment and performance did not occur directly, but depended on other variables (Sawitri, 2009). That study explained that the influence of employees' commitment on performance depended on the distance from power. Thus, the findings of this study provide opportunities to identify further the variables which can explain the relationship between students' commitment to lecturers and students' performance. 


\section{CONCLUSIONS AND SUGGESTIONS}

\section{Conclusions}

So far students could see distributive justice and procedural justice in lecturers' evaluation of their performance (GPA). The justice students saw significantly raised their commitment to lecturers, however students' commitment did not significantly improve their GPA. Thus, the suspection that lecturers' evaluation of students' performance was done as by lottery was not true.

The practical implications of the results of this study are as follows:

1. Lecturers should apply justice in determining students' grades and in the procedure of determining the grades.

2. Lecturers should try to know the cause why students' commitment to lecturers can not improve students' performance which indicates that students' commitment is merely to meet lecturers' demands and not to achieve better performance which is seen in the improvement of GPA.

The theoretical implications of the results of this study are as follows:

1. The conclusions of this study can add insights to the development of sciences related to the influence of distributive justice and procedural justice on commitment, which in turn will improve performance.

2. Add the generalization of results of studies in the context of competency-based learning evaluation for university or college students.

\section{Limitations}

1. The questionnaire was arranged in five scale answers, one of which was "neutral" answer which enabled students who were in doubt to choose the neutral answer.

2. The random sampling was initially planned from students of Economics Department, Agricultural Department, Engineering Department, and Social Politics Department. However, since at the time of sampling Agricultural Department students had a holiday, they were changed by students of Mathematics and Natural Sciences Department. This might cause the sampling to be less representative.

\section{Suggestions}

1. Concerning variable measurements, it is necessary to review alternative measurements especially commitment to lecturer variable, since there were seven invalid items out of 17 items. Besides, it is better to use a scale of four in order to prevent "neutral" answer from respondents who are in doubt.

2. The time of sampling should be arranged more carefully in order to prevent change of sample.

\section{REFERENCES}

Ali, N. \& Jan, S. 2012. Relationship between Organizational Justice and Organizational Commitment and Turnover Intentions amongst Medical Representatives of Pharmaceuticals Companies of Pakistan. Journal of Management Sciences, 6(2): 201-212.

Becker, T. E. 1992. Foci and Bases of Commitment: Are They Distinctions Worth Making? Academy of Management Journal, 35(1): 232-244.

Becker, T. E., Billings, R. S., Eveleth, D. M., \& Gilbert, N. L. 1996. Foci and Bases of Employee Commitment: Implications for Job Performance. Academy of Management Journal, 39(2):464482.

Becker, T. E. \& Kernan, M. C. 2003. Matching Commitment to Supervisors and Organizations to Inrole and Extrarole Performance. Human Performance, 16(4): 327-348.

Burke, J. 1995. Theoretical Issues in Relation to Jessup's Outcomes Model. In Burke, J. (Ed.), Outcomes, Learning, and the Curriculum (pp. 55-82). London: Falmer.

Chen, Z. X., Tsui, A. S., \& Farh, J. L. 2002. Loyalty to Supervisor vs. Organizational Commitment: Relationships to Employee Performance in China. Journal of Occu-pational and Organizational Psychology, 75(3): 339-356.

Colquitt, J. A. 2001. On the Dimensionality of Organizational Justice: A Construct Validation of a Measure. Journal of Applied Psychology, 86(3): 386-400.

Colquitt, J. A., Conlon, D. E., Wesson, M. J., Porter, C. O. L. H. \& Yee Ng, K. 2001. Justice at the Millennium: A Meta-Analytic Review of 25 Years of Organizational Justice Research. Journal of Applied Psychology, 86(3): 425-445.

Cooper, D. R. \& Schindler, P. S. 2003. Business Research Methods. $8^{\text {th }}$ Edition. Boston: McGraw Hill.

Hair, J. F., Black, W. C., Babin, B. J., \& Anderson, R. E. 2009. Multivariate Data Ana-lysis. $7^{\text {th }}$ Edition. Upper Saddle River: Pearson Prentice Hall.

Hartono, J. 2004. Metodologi Penelitian Bisnis. Yogyakarta: BPFE. 
Hemdi, M. A. \& Nasurdin, A. M. 2006. Predicting Turnover Intentions of Hotel Employees: The Influence of Employee Development Human Resource Management Practices and Trust in Organization. Gadjah Mada International Journal of Business, 8(1): 21-42.

Jaros, S. J. 1997. An Assessment of Meyer and Allen's (1991) Three-component Model of Organizational Commitment and Turnover Intensions. Journal of Vocational Behavior, 51(3): 319-337.

Joglosemar, 20 Maret 2010. Akademia.

Kelidbari, H. R., Dizgah, M. R., \& Yusefi, Azim. 2011. The Relationship Organizational Commitment and Job Performance of Employees of Guilan Province Social Security Organization. Interdisciplinary Journal of Contemporary Research in Business, 3(6): 555-568.

Leventhal, G. S. 1980. What Should be Done with Equity Theory. New York: Plenum Press.

Meyer, J. P. \& Allen, N. J. 1991. A Three-Component Conceptualization of Organizational Commitment. Human Resource Management Review, 1(1): 61-89.

Meyer, J. P., Allen, N. J., \& Smith, C. A. 1993. Commitment to Organization and Occu-pations: Extension and Test of Three-Component Conceptualization. Journal of Applied Psychology, 78(4): 538-551.

Meyer, J. P. \& Smith, C. A. 2000. HRM Practices and Organizational Commitment: Test of a Mediation Model. Canadian Journal of Administrative Sciences, 17(4): 319-331.

Nasrudin, A. M. \& Ahmad, Z. A. 2000. Does Gender Moderate The Effect of Proce-dural Justice on Organizational Commitment Among Malaysian Employees? School of Management, Universiti Sains Malaysia.

Qaisar, M. U., Rehman, M. S., \& Suffyan, M. 2012. Exploring Effects of Organizational Commitment on Employee Performance: Implication for Human Resource Strategy. Interdisciplinary Journal of Contemporary Research Business, 3 (11): 248-255.

Reichers, A. E. 1985. A Review and Reconceptualization of Organizational Commitment. Academy of Management Review, 10(3): 465476.
Rhoades, L., Eisenberger, R., \& Armeli, S. 2001. Affective Commitment to the Organization: The Contribution of Perceived Organizational Support. Journal of Applied Psychology, 86(5):825836.

Sawitri, H. S. R. 2009. Komitmen pada Organisasi versus Komitmen pada Supervisor: Pengaruhnya pada Kinerja Tugas dan Perilaku Kewargaan Organisasional bagi Karyawan dengan Persepsi Jarak Kekuasaan Berbeda. Disertasi. Yogyakarta: Universitas Gadjah Mada.

SK Mendiknas RI No. 232/U/2000.

SK Mendiknas RI No: 045/U/2002.

Skarlicki, D. P. \& Folger, R. 1997. Retaliation in the Workplace: The Roles of Distributive, Procedural, and Interactional Justice. Journal of Applied Psychology, 82 (3): 434-443.

Solikhin, M. \& Pike, R. 2009. Fairness Evaluation and Its Behavioral Consequences. Accounting and Business Research, 39(4): 397-413.

Somers, M. J. \& Birnbaum D. 1998. Work-related Commitment and Job Performance: It's Also the Nature of the Performance that Counts. Journal of Organizational Behavior, 19(6): 621-634.

Suliman, A. \& Iles, P. 2000. Is Continuance Commitment Beneficial to Organizational? Commitment-performance Relationship: A New Look. Journal of Managerial Psychology, 15(5): 407426.

Tang, T. L. \& Sarfield-Baldwin, L. J. 1996. Distributive Justice and Procedural Justice as Related to Satisfaction and Commitment. S. A. M. Advanced Management Journal, 61(3): 25.

Tantra, D. K. 2009. Kurikulum Berbasis Kompetensi. Denpasar: ISI.

Thibaut, J. \& Walker, L. 1975. Procedural Justice: A Psychological Analysis. Hillsdale: Lawrence Erlbaum Associates.

Witt, L. A., Kacmar, K. M., \& Andrews, M. C. 2001. The Interactive Effects of Procedural Justice and Exchange Ideology on Supervisorrated Commitment. Journal of Organizational Behavior, 22: 505-515. 